\title{
FIFTY YEARS OF THE WELLCOME TRUST
}

\author{
EDITORIAL
}

Since its creation in 1936, the Wellcome Trust has carried out the wishes of its founder in the promotion of research in medical science and in the history of medicine. Its achievements have been recently chronicled by A. R. Hall and B. A. Bembridge in a volume reviewed on pp. 473-475 below, and, more briefly, by Lord Franks in the following retrospect. It would be superfluous here to describe the role of the Wellcome Trust in the development of medical research, but its importance for the history of medicine cannot be underestimated. Without the support of the Wellcome Trustees, the history of medicine in the United Kingdom would scarcely exist as an academic discipline, or as more than local antiquarianism, and historians from all over the world would be deprived of the rich resources of the Wellcome Library and the Wellcome Galleries at the Science Museum. In congratulating the Trust on its golden jubilee, historians of medicine everywhere must also express their grateful thanks for the Trustees' ongoing commitment to the ideals of its founder.

\section{THOUGHTS ON THE WELLCOME TRUST 1963-82}

\author{
by
}

\section{LORD FRANKS, OM}

I became a Wellcome Trustee in 1963 and Chairman of the Trust two years later: I served as Chairman until I retired in 1982. By coincidence, I arrived on the scene at a time of major change. The Old Guard among the Trustees and the Secretariat were retiring and new faces were appearing. Above all, for the first time, the Trust's annual income from the Wellcome Foundation ${ }^{1}$ had reached $£ 1,000,000$ or more, with every prospect of an income of this size being maintained or increased. All this indicated that the moment had come to look at how the activities of the Trust should be organized and what policies should be followed.

The years from 1936, when the Trust was set up after the death of Sir Henry Wellcome, had been full of difficulties. Before the war, payment of death duties on Sir Henry's estate had absorbed the attention of the Trustees and all the money that might

${ }^{1}$ In order to prevent confusion, readers should remember that the Wellcome Foundation is the international pharmaceutical company, until recently wholly owned by the Wellcome Trust, a registered charity. The Wellcome Trust will continue to retain the controlling interest in the Wellcome Foundation. 